\title{
The Relationship, Tension and Interaction between Cultural Imperialism and Contra-Flow in Contemporary Media Culture
}

\author{
Yue Lu \\ Institute of Communications Studies, University of Leeds, Leeds, UK \\ Email: cs12yl@leeds.ac.uk, abraham.lu@hotmail.com
}

Received November $2^{\text {nd }}, 2013$; revised December $4^{\text {th }}$, 2013; accepted December $13^{\text {th }}, 2013$

\begin{abstract}
Copyright (c) 2013 Yue Lu. This is an open access article distributed under the Creative Commons Attribution License, which permits unrestricted use, distribution, and reproduction in any medium, provided the original work is properly cited. In accordance of the Creative Commons Attribution License all Copyrights (C) 2013 are reserved for SCIRP and the owner of the intellectual property Yue Lu. All Copyright $@ 2013$ are guarded by low and by SCIRP as a guardian.
\end{abstract}

\begin{abstract}
This study discusses the interaction between cultural imperialism and contra flow in the context of contemporary media culture, mainly looking at the perspective of visual media such as television and movie other than print media. It talks about the relationship between cultural imperialism and dominant flow in global cultural industries. It also explores the relationship between dominant flow and contra-flow and how they influence and challenge each other. Although the wide use of satellite and cable television as well as the increasing use of online communication has enabled the flows of international culture in a multi-national, multi-media and multi-directional movement instead of a one-way model — from the West to the rest of the world, the market share of non-western media content products is still small compared to that of the western media content products. And most globally popular cultural genres are still from the West. Whilst contra-flow may somehow challenge the dominant position of the West in global cultural industries, it is still short of the power to reverse such situation.
\end{abstract}

Keywords: Cultural Imperialism; Contra-Flow; Dominant Flow; Media

\section{Introduction}

In the 1970 s and early 1980 s, when the term "cultural imperealism" was at its most popular stage, many scholars started to study the relationship between cultural imperialism and the flows of global culture. Debates have been very fierce since that time, as some contend that cultural imperialism has played a role in terms of the Western domination in international cultural flows, whereas others react against the cultural imperialism thesis and prefer to the term "globalization" (Hesmondhalgh, 2007). Advocates for the term "globalization” like Giddens and Robertson argue that Western society's domination in global cultural flows is more of a byproduct of globalization rather than an outcome generated by cultural imperialism. However, the proliferation of Western culture, with the USA at its core, is more than mere accident (Galeota, 2004). There must be a hand behind the popularization of Western products across the world. It is likely that cultural imperialism is that hidden hand.

As time goes on, another force called "contra-flow" comes into play. The advent of it challenges the predominate position of the West concerning the flows of international culture. The flows of global culture are no longer merely from the West to the rest, but a two way movement. As what the UNESCO World Culture Report presented in the late 1990s, “media globalization has triggered possibilities of other models based on different cultural, institutional, and historical backgrounds... such alternatives are likely to multiply in the era of globalization, in spite of appearances, which may paradoxically witness greater diversity than uniformity" (UNESCO, 1998: p. 23). My aim in this essay is to outline a frame of global cultural flows so as to examine the relationship, tension and interaction between cultural imperialism and contra-flow at a phenomenal level other than a theoretical one.

My concentration is on the dominant flow and contra-flow of international culture by looking at the perspective of media, mainly television and movie instead of print media such as newspaper and magazine. The essay will discuss the term "dominant flow" on the basis of cultural imperialism in the first place. It then goes on to explore the term "contra-flow" and the relationship between it and dominant flow. While contra-flow may, in a way, challenge the dominant position of the West in global cultural industries, it is still short of the power to reverse such domination.

\section{Background}

Since the end of the Second World War, the flow of global culture has become a focus in the studies of international communication. Normally, two factors have played an important role in current international cultural industries; they are dominant flow and contra-flow. Generally speaking, dominant flow refers to the domination of the West, led by the US, in global cultural industries, whereas contra-flow represents the role of the non-Western society concerning the circulation of international culture. Since these two flows are of great significance in the development of nowadays global cultural market, many scholars start to study the relationship between them. What I 
argue in this essay is that the relationship between dominant flow and contra-flow is complicated. The spread of dominant flow contributes to the development of contra-flow, and contraflow in turns, challenges the power of dominant flow. However, contra-flow is still lack of the ability to reverse such power. By studying the relationship between dominant flow and contraflow, we can somehow understand the relationship between cultural imperialism and contra-flow as well. Since dominant flow is an outcome generated by the spread of cultural imperialism, it would be fair to say that the relationship between cultural imperialism and contra-flow is similar to the relationship between dominant flow and contra-flow. That is to say, cultural imperialism, in a sense, triggers the development of contraflow, and when contra-flow becomes stronger, it becomes threatening the status of cultural imperialism. But this threat is not powerful enough to have a significant influence on stopping cultural imperialism to occur around the world.

Because the dissemination of culture is largely based on the development of media, this essay will explore the relationship between dominant flow and contra-flow from the perspective of media, principally visual media such as television and movie, since they attach great significance to the circulation of international cultural products, and since they have a much larger audience base than print media such as newspaper and magazine. Let us first start with the term "dominant flow" and its connection with cultural imperialism in a more specific way.

\section{Dominant Flow}

The US-led Western media which are global in their reach and influence (Boyd-Barrett, 2006; Thussu, 2006) are what people always termed as "dominant media flow". Owing to the economic and political power of the United States, its media "are now available across the globe, if not in English then in dubbed or indigenized versions" (Thussu, 2007: p. 12). The only media genre with a global popularity that is not emanated from the US-led West is Japanese animation. "From news and current affairs (CNN, Discovery) through youth programming (MTV), children's television (Disney), feature film (Hollywood), sport (ESPN) to the Internet (Google), the United States is the global behemoth" (Thussu, 2007: p. 12). Of such great power in terms of disseminating international culture, dominant flow has become a focus among scholars in communication studies. People begin to wonder: how did dominant flow come into being? This question triggers many issues such as the power of capitalist economy, the role of political power and the impact of symbolic form and content in deciding developments in the cultural industries (Hesmondhalgh, 2007). I attribute the answer for this question to the term "cultural imperialism".

\section{Cultural Imperialism and Its Connection with Dominant Flow in Global Culture Industries}

The term "cultural imperialism" does not have a particularly long history (Tomlinsom, 2002: p. 2). It emerged just in the 1960s but thereafter, it has been a focus of research among scholars, largely communication studies. Definitions of cultural imperialism are of various versions. It may refer to the way that "the cultures of less developed countries have been affected by flows of cultural texts, forms and technologies associated with the West" (Hesmondhalgh, 2007: p. 214). It may also refer to the conquest of one country by a more powerful one without the involvement of economic exploitation and military force. In his book Communication and Cultural Domination, Schiller defines cultural imperialism as "the sum of the processes by which a society is brought into the modern world system and how its dominating stratum is attracted, pressured, forced, and sometimes bribed into shaping social institutions to correspond to, or even promote, the values and structures of the dominating center of the system" (Schiller, 1976: p. 9). Therefore, cultural imperialism is much more complicated than a mere consumption of Western commodities; it involves in "the imposition of Western cultural products on the non-West, the potentially homogenizing effects of Western culture as it spread across the world and the destruction of indigenous traditions by such cultural flows" (Sreberny, 1997: p. 49).

According to UNESCO's 2005 report on International Flows of Selected Goods and Services, the value of the cultural Industries in the world was 1.3 trillion dollars and was expanding at a rapid rate. Merely in the duration of 1994 to 2002, global trade in cultural products grew from 38 billion to 60 billion dollars. (UNESCO, 2005a) Being aware of the power of culture and the profit behind it, many nations have quickly embraced the thesis of cultural imperialism and continued to utilize it as an instrument to control the global cultural industries. Among these nations, the USA is the most eminent one. Desire for access to foreign markets (Galeota, 2004) and ambition to enlarge the influence of the America across the globe have become the motivation behind American cultural imperialism. Indeed, the active role of the USA government is a very important factor concerning its domination in global cultural industries and the promotion of American culture abroad. In international forums, for instance, such as UNESCO since the end of the Second World War, delegates from the America spare no effort underlining the importance of a free flow of information and entertainment across the world, which to a large degree, facilitates the spread of American culture across the world (Schiller, 1998). In addition, the US government has been very active in establishing its media market since the end of the Second World War. Its mature media market has benefited the USA's control in global cultural industries in a long term, allowing it to reduce costs at home and seek foreign markets as sources of further profit (Hesmondhalgh, 2007). Meanwhile, it also spends considerable amount of funds on the construction of communication infrastructures such as satellites. These are all evidences that prove the "cultural imperialism" thesis; they consolidate the notion that the dominant flow in global cultural industries is more of a result of cultural imperialism which pushed by the USA rather than merely a byproduct of globalization. In short, the spread of cultural imperialism leads to the emergence of dominant flow.

\section{Contra-Flow and Its Relationship with Dominant Flow}

"In parallel with the globalization of the Western culture, new transnational networks have emerged. These new networks, emanating from such Southern urban creative hubs as Cairo, Hong Kong and Mumbai, represent what could be called contra-flow" (Thussu, 2007: p. 23). In Thussu's book Media on the Move: Global Flow and Contra-flow (2007), Kavoori defines "contra-flow" as: "the semantic and imaginative referents for the institutional, cultural and political matrix of a world framed by processes of global cultural power and local negotiation: a world experienced through the identity politics of na- 
tions, individuals and cultures and negotiated through contestations of locality, nationality and global citizenship” (49). Thus, "contra-flow" is about the movement of cultures from one place to another, like a two way traffic-lane, where individuals are said to live "between cultures" (Thussu, 2007). Differs from "dominant flow", "contra-flow" derives from the less powerful regions of the world, or to say, the peripheries of global media industries. "Contra-flow" has emerged in that global mass media programming is reversing the dominant (Western) direction; flows of global culture are no longer from the West to the rest but a two-way movement. (Kavoori, 2007) The development of Indian movie industry (popularly referred to as Bollywood), the spread of Latin American telenovel (always referred to as soap opera), the rise of East Asian "Wave" (often represented by South Korean) and the expansion of CCTV-9 of China are all examples of contra-flow. The following paragraphs will use some of these contra-flows as examples to illustrate the relationship between contra-flow and dominant flow in specific.

There is often a misunderstanding in terms of the relationship between dominant flow and contra-flow as some maintain that the existence of dominant flow largely smother the possibility for contra-flow to grow. Nevertheless, this notion is too simple to depict the whole picture behind dominant flow and contraflow. The relationship between these two flows involves in a much more complex way. The globalization of Western or westernized media flows across the world, in a way, inspires the development of contra-flow, and as contra-flow becomes stronger, it begins to challenge the dominant position of the West in global industries but so far it cannot reverse such domination as imbalance between the dominant and contra media flow in the world is still manifest.

Whilst the globalization of Western media has increased Western culture's influence, it also contributes to the development of contra-flow. The flow of western media products across the globe, exemplified by the proliferation of the American movie and television exports, has inspired the development of non-Western media organizations, opening up new opportunity for the flow of media content across the world. As many US-led Western media conglomerates have successfully localized their content to make their media products globally popular, media organizations from the non-Western society have benefited from this process. Some of these media organizations have smartly learned from the successful experience of those Western media conglomerates, and then skillfully applied to their own media products so as to make them go globally. Moreover, 'the globalization of Western or Western inspired media has also contributed to the creation of professional careers in media and cultural industries by stimulating the formation of important global hubs for creative industries (Thussu, 2007: p. 13). In a sense, dominant flow spurs the emergence of contra-flow.

As contra-flow becomes stronger, it somehow challenges the power of dominant flow. It is no doubt that the traffic of global media nowadays is not just one way-from the West to the rest-but a two way movement. Over the last decade, the world has witnessed an increasing growth of non-Western media content originating from creative hubs like Hong Kong, Cairo and Mumbai (Banerjee, 2002). The access of digital technology, satellite and broadcasting networks and the physical movement of people around the world have contributed to the growing flow of media content from the non-Western society to the Western society (Thussu, 2007). Non-Western nations such as
India, Japan, South Korean and Brazil have become more and more crucial in terms of the circulation of international culture. From Latin America telenovela and Indian movie industry to regional broadcasting like the mandarin language Phoenix channel and the 24/7 news network Al-Jazeera, contra-flow has become an indispensable factor in distributing global culture.

One key instance of contra-flow is the Latin America telenovela. Since the late 1970 s, Latin American telenovelas have been exported to the America, Europe, Asia, Africa, and the Middle East. "Their worldwide success suggests that they are no longer a uniquely Latin American phenomenon but a major global commercial force with extraordinary social and cultural importance” (Rego \& Pastina, 2007: p. 100). Leading by Brazil and Mexico, this transnational telenovelas has been produced by many Latin American nations such as Venezuelan and Colombian, and has been widely exported to the rest of the world. By 2005, as Thussu quoted Martinez (2005) in his book Media on the Move, "the telenovela had developed into a 2 billion dollars industry, of which 341 million dollars was earned outside the region, being broadcasted in 50 languages and reaching over 100 countries from Latin America to Europe, Asia, Africa and the Arab world” (2007: p. 25). Merely Brazilian telenovelas have been exported to more than 130 countries across the world. In 2005 alone, over 30 Brazilian telenovelas were aired in more than 20 nations around the world, programming more than 10,000 hours. The same year, the number of subscribers of the Brazilian TV Globo reached almost 2 million internationally. The presence of Latin American telenovela, challenges the conventional West-to-non-West cultural and media flow. It also challenges the hegemony of Hollywood's cultural exports since Latin American telenovela has a strong local cultural root (Rego \& Pastina, 2007).

Another key example of contra-flow is the Indian movie industry as always referred to Bollywood. "Given its size and diverse social and cultural antecedents, India is among the few non-Western countries to have made their presence felt in the global cultural market” (Thussu, 2007: p. 26). The increasing international visibility of India is largely dependent on its movie industry - the Bollywood. Benefited from the development of digital technology and expansion of television, the movie industry of India has witnessed a leap since the early 2000s, with numerous Indian movies are now shown regular across the world. Each year, more than one billion more people buy tickets for Indian movies than for Hollywood movies, and the quantity of movie produced by India every year has also transcended the Hollywood's. Currently, Indian movies are shown in more than 70 nations across the world. In spite of their popularity in the Arab world and central Southeast Asia, Indian movies have also reached to the Western society, for example, Dil Se (1998) was among the top ten box offices in Britain in 1998 and Taal (1999) was among the top twenty in the United States (Govil, 2007). From 1989 to 1999, Indian movie exports saw a five-fold growth: the exports of Indian movies increased from 20 million dollars in the early 1990s to 100 million dollars by the end of the 1990s. "In 2000, Bollywood held a celebration of its own at International Indian Film Awards ceremony at London's Millennium Dome with the show broadcasted lively to over 120 countries" (Govil, 2007: p. 85). The same year, Missin Karshmir (2000), became the first Indian movie to release in New York's Times Square after Sony obtained the overseas rights of it. In 2002, Lagaan (2001) was nominated among the Best Non-English movies in 2002 
Academy Awards in the America. In 2003, the word "Bollywood" was officially listed in the Oxford English Dictionary. All of these are proofs that Bollywood has risen as an international cultural force.

Nevertheless, neither Latin American telenovela nor Bollywood is a clear example of a non-Western cultural product becoming a global commodity, and the growing trend of contra-flow in recent years may give "a false impression that the world communication has become more diverse and democratic" (Thussu, 2007: p. 27). The revenues of non-Western media corporations are still small compared to those from the West. According to the US government's Bureau of Economic Analysis, US revenues of film and television have kept a stable growth from 2.5 billion to 10.4 billion dollars from 1992 to 2004. In film industry, US domination is the most manifest. Hollywood movies are shown in over 150 nations across the world and are predominant in terms of market share. Take the 2004 European market as an example. In Europe, "nearly 72 percent of movies shown in 2004 were from Hollywood, over 25 percent were European, and just over 2 percent of market share belonged to the rest of the world" (Thussu, 2007: p. 19). None of the Latin American telenovelas and the Bollywood movies can reach the same impact of US television series and movies. In addition, dominant flow itself is becoming stronger as well. The top entertainment companies are still from the United States, for instance, Walt Disney, Time Warner and News Corporation. The world's most influential television network is still America based such as CNN and Discovery Channel. Therefore, contra-flows from non-Western nations are still unlikely to have a significant influence on the US-led West hegemony of global cultural industries, or to say, cultural imperialism.

\section{Conclusion}

Flows have been increasingly significant in current global society as Manuel Castells has argued in his book The Rise of the Network Society that our contemporary life is dominated and constructed by flows. "They are not just one element of the social organization but the expression of processes dominating our economic, political and symbolic life" (Castells, 2000: p. 442). Two flows play a significant role in nowadays global cultural industries. One is the dominant flow, emanating mainly from the West; the other is the contra-flow, originating from the Third World. Decades ago, with the rise of cultural imperialism, dominant flow almost controlled the whole global cultural industries. The only non-Western cultural product with a global popularity was the Japanese animation. As times go on, contra-flow has gradually become a force that changes the landscape in terms of the circulation of contemporary global culture. The advent of contra-flow, with the help of the popularization of satellite and cable television and the increasing use of online communication, has enabled the flows of international culture in a multi-national, multi-media and multi-directional movement instead of a one-way model-from the West to the rest of the world. Non-western media content like the Latin American telenovela and Bollywood movie is now spreading across different continents, bestowing audiences with opportunities to taste different cultures and challenging the dominant position of the West in global cultural industries. However, the growing trend of contra-flow in recent years is not an indication that the world communication has become more diversified. Compared with the West-oriented media organizations, market share of non-Western media ones is still small and most globally popular cultural genres are still from the West. Dominant flow is still prevailing in its relationship with contra-flow and this trend is very likely to be going on in the future.

\section{REFERENCES}

Banerjee, I. (2002). The locals strike back? Media globalization and localization in the new Asian television landscape. Gazette, 64, 517535.

Boyd-barrett, O. (2006). Cyberspace, globalization and empire. Global Media and Communication, 2, 21-41. http://dx.doi.org/10.1177/1742766506061815

Castells, M. (2000). The space of flows. The rise of the network society (pp. 440-450). London: Blackwell.

Galeota, J. (2004). Cultural imperialism: An American tradition. http://www.thehumanist.org/humanist/articles/essay3mayjune04.pdf

Government, U. (2005). US international services: Cross-border trade in 2004.

http://www.bea.gov/scb/pdf/2005/10October/1005_xborder.pdf

Govil, N. (2007). Bollywood and the frictions of global mobility. In D. K. Thussu (Ed.), Media on the move: Global flow and contra-flow (pp. 84-98). London: Routledge.

Hesmondhalgh, D. (2007). Internationalisation, globalisation and cultural imperialism. The cultural industries (pp. 212-236). London: Sage.

Kavoori, A. P. (2007). Thinking through contra-flows: Perspectives from post-colonial and transnational cultural studies. In D. K. Thussu (Ed.), Media on the move: Global flow and contra-flow (pp. 49-50). London: Routledge.

Pastina, C. M. R. A. A. C. L. (2007). Brazil and the globalization of telenovelas. In D. K. Thussu (Ed.), Media on the move: Global flow and contra-flow (pp. 99-115). London: Routledge.

Schiller, H. I. (1976). Introduction. Mass communication and cultural domination (pp. 1-15). White Plains, NY: International Art and Sciences Press.

Schiller, H. I. (1998). Striving for communication dominance: A half century review. In D. Thussu (Ed.), Electronic empire (pp. 17-26), London: Arnold.

Sreberny, A. (1997). The many culutral faces of imperialism. In P. G. A. P. Harris (Ed.), Beyond cultural imperialism (pp. 49-70). London: Sage.

Thussu, D. K. (2006). International communication: Continuity and change. London: Arnold.

Thussu, D. K. (2007). Mapping global media flow and contra-flow. In D. K. Thussu (Ed.), Media on the move: Global flow and contra-flow (pp. 11-32). London: Routledge.

Tomlinson, J. (2002) The discourse of cultural imperialism. Cultural Imperialism: a critical introduction. New York: Continuum.

Unesco. (1980). Many voices, one world (The MacBride report). Paris: UNESCO.

http://unesdoc.unesco.org/images/0004/000400/040066eb.pdf

UNESCO (1998). World culture report 1998: Culture, Creativity and markets. Paris: United Nations Educational, Scientific and Cultural Organization.

UNESCO (2005a). International flows of selected cultural goods 19801998. UNESCO Institute for Statistics. Paris: United Nations Educational, Scientific and Cultural Organization. 